\title{
PENGARUH PEMBERIAN SAGU DIBANDING NASI TERHADAP BERAT BADAN TIKUS WISTAR
}

\author{
${ }^{1}$ Eny A. Watumlawar \\ ${ }^{2}$ Sarah M. Warouw \\ ${ }^{2}$ Stefanus Gunawan
}

\author{
${ }^{1}$ Kandidat Skripsi Fakultas Kedokteran Universitas Sam Ratulangi Manado \\ ${ }^{2}$ Bagian Ilmu Kesehatan Anak Fakultas Kedokteran Universitas Sam Ratulangi Manado \\ Email: enywatumlawar_11_266@yahoo.com
}

\begin{abstract}
Weight is one measure that gives description of the tissue mass including body fluids. Weight change is nfluenced by nutriment consumption. Sago contains high carbohydrates that can increase body weight. This study aimed to obtain the effect of sago compared to rice to body weight of wistar rats. This was a random laboratory experimental pre-post test with control group design. Subjects were male wistar rats, aged 5-6 months. The rats were divided in two groups: rice group as control and sago group. Sago was cooked in papeda form as much as $75 \mathrm{~g}$ of dried sago and $300 \mathrm{~mL}$ water. The rats were fed for 2 weeks. Data were analyzed by using the Wilcoxon test. The results showed that the sago group showed an increase of body weight significantly $(\mathrm{p}=0,001)$ meanwhile the rice group lose body weight significantly $(p=0,001)$. Conclusion: Sago can increase body weight of wistar rats significantly.
\end{abstract}

Keywords: body weight, sago, rice

\begin{abstract}
Abstrak: Berat badan merupakan salah satu ukuran yang memberikan gambaran massa jaringan termasuk cairan tubuh. Salah satu yang memengaruhi berat badan yaitu dengan mengonsumsi makanan bergizi. Sagu memiliki kandungan karbohidrat (pati) yang besar dan dapat meningkatkan berat badan. Penelitian ini bertujuan untuk mengetahui pengaruh pemberian sagu terhadap berat badan dibanding nasi pada tikus wistar. Desain penelitian ini ialah eksperimental laboratorium acak pre-post test with control group design. Subjek penelitian ialah tikus wistar jantan berusia 5-6 bulan dibagi atas 2 kelompok: kelompok nasi (kontrol) dan kelompok sagu. Sagu dimasak dalam bentuk papeda sebanyak $75 \mathrm{~g}$ sagu kering dan $300 \mathrm{~mL}$ air. Tikus diperlihara selama 2 minggu. Berat badan diukur dengan menggunakan timbangan. Data dianalisis dengan uji Wilcoxon. Hasil penelitian menunjukkan bahwa pemberian sagu sebanyak 2 cc setiap hari selama seminggu mampu meningkatkan berat badan secara bermakna $(p=0,001)$ sedangkan pemberian nasi menurunkan berat badan $(p=0,001)$.
\end{abstract} Simpulan: Pemberian sagu dapat meningkatkan berat badan tikus wistar secara bermakna.

Kata kunci: berat badan, sagu, nasi

Berat badan merupakan salah satu ukuran yang memberikan gambaran massa jaringan termasuk cairan tubuh. Berat badan sangat peka terhadap perubahan yang mendadak baik karena penyakit infeksi maupun mengkonsumsi makanan. ${ }^{1}$

Berbagai jenis bahan makanan yang sering dikonsumsi adalah makanan yang mengandung karbohidrat, protein, lemak, vitamin dan gizi lainnya. Semua kandungan gizi ini diperlukan didalam tubuh bagi pertumbuhan. Masa pertumbuhan yang paling optimal yaitu pada masa anak-anak. Salah satu kandungan gizi terpenting dalam tubuh ialah karbohidrat yang dijadikan sebagai sumber bahan makanan pokok, 
karena selain tinggi kadar amilumnya, juga dapat dimakan dalam jumlah besar. Bahan makanan pokok yang ada di Indonesia dapat berupa beras (serealia), akar, dan umbi serta ekstra tepung seperti sagu. ${ }^{2}$

Sagu merupakan tanaman penghasil pati yang sangat potensial namun pemanfaatannya masih sangat terbatas. Tanaman sagu banyak dijumpai di daerah Indonesia bagian timur khususnya Papua dan Maluku. Masyarakat disanapun masih menjadikan jenis makanan ini sebagai makanan pokok mereka, mereka sering mengkonsumsinya dalam bentuk yang bervariasi seperti papeda, ongol-ongol, kapurung, bagea dan lainnya. Bahkan di Maluku, ibu-ibu secara rutin memberikan "papeda" kepada bayi di atas 6 bulan. Mereka mengatakan bahwa bobot badan bayinya bertambah secara luar biasa atau dalam istilah sehari-hari "body pica-pica" atau badan besar kuat dan sehat. ${ }^{3}$ Demikian pula dengan anak-anak dan orang dewasa yang kegemarannya mengonsumsi "papeda" dengan ikan kuah kuning pakai kenari membuat hidupnya terasa sehat dan bugar. ${ }^{4}$ Hasil penelitian yang dikemukakan oleh Papilaya pada tahun 2009 bahwa sagu dalam bentuk papeda yang dikonsumsi oleh bayi di atas 6 bulan dapat menambah bobot badan bayi secara luar biasa. Hal ini membuat peneliti tertarik untuk melakukan penelitian tentang pengaruh pemberian sagu terhadap berat badan yang akan dilakukan pada hewan coba.

\section{METODE PENELITIAN}

Metode penelitian yang digunakan dalam penelitian ini ialah eksperimental laboratorium dengan rancangan penelitian acak pre-post test with control group design. Penelitian dilakukan di Laboratorium Terpadu FK UNSRAT. Sampel yang digunakan pada penelitian ini ialah tikus Wistar

\section{HASIL PENELITIAN \\ Karakteristik subjek}

Penelitian ini dilakukan pada minggu I dan II bulan Januari 2015, diawali aklimatisasi selama satu minggu dengan jumlah sampel sebanyak 30 ekor tikus wistar jantan (Rattus norvegicus) dipelihara dengan menggunakan kandang individual. Sampel dibagi dalam dua kelompok yaitu kelompok perlakuan 15 ekor tikus wistar jantan yang diberi makan sagu dan kelompok kontrol 15 ekor tikus wistar jantan yang diberi makan nasi. Kedua kelompok sampel diberi makan dengan ukuran yang sama yaitu dengan menggunakan sonde sebanyak 2cc.

\section{Hasil pengukuran berat badan}

Hasil pengukuran berat badan sebelum dan sesudah diberi makan sagu dan nasi menunjukkan bahwa nilai rerata pada kelompok tikus yang diberi makan sagu menunjukkan peningkatan dari 186,33 g menjadi 219,33 g.

Tabel 1. Hasil rerata berat badan tikus (dalam gram) dengan pemberian sagu dan nasi

\begin{tabular}{ccccc}
\hline & \multicolumn{2}{c}{ Sagu } & \multicolumn{2}{c}{ Nasi } \\
\cline { 2 - 5 } & Pre & Post & Pre & Post \\
\hline Rerata & 186,33 & 219,33 & 194,67 & 165,33 \\
SD & 15,637 & 15,453 & 8,121 & 19,130 \\
Median & 190,00 & 220,00 & 195,00 & 170,00 \\
\hline
\end{tabular}

\section{Hasil perhitungan dengan menggunakan} Uji Wilcoxon

Berdasarkan hasil pengukuran berat badan sebelum dan sesudah diberi makan sagu dan nasi dengan menggunakan Uji Wilcoxon memperoleh nilai $\mathrm{p}$ yang signifikan $(<0,05)$.

Tabel 2. Hasil perhitungan dengan menggunakan Uji Wilcoxon

\begin{tabular}{ccc}
\hline & Selisih rerata & Nilai p \\
\hline Sagu & 33,000 & $0,001^{*}$ \\
Nasi & $-29,333$ & $0,001^{*}$ \\
* bermakna secara statistik $(\mathrm{p}<0,05)$
\end{tabular}

\section{BAHASAN}

Dalam penelitian ini, hewan coba tikus wistar jantan yang diberi sagu mengalami peningkatan berat badan. Setelah 7 hari diberi perlakuan, hasil penelitian yang diperoleh dari kelompok sagu dari data statistik nilai rerata yaitu peningkatan berat 
badan sebesar 186 g menjadi 219 g dan selisih rerata kelompok sagu 33,000 dengan nilai $\mathrm{p}=0,001$ yang menunjukkan bahwa terdapat peningkatan secara bermakna yang diuji dengan Uji Wilcoxon.

Hasil data statistik yang diperoleh menunjukkan bahwa pada kelompok sagu terdapat peningkatan berat badan (Tabel 1). Dengan kata lain, pemberian sagu pada hewan uji melalui penelitian ini memberikan kandungan gizi (pati) yang besar dibandingkan kelompok pangan lainnya. Komponen yang sangat penting dari tepung sagu ialah karbohidrat, kirakira 84,70\% dari bahan keringnya. Sagu mengandung karbohidrat yang lebih tinggi dibanding beras. Beras hanya mengandung karbohidrat sekitar 78,90\%., ${ }^{1,2}$

Penyerapan karbohidrat di dalam tubuh dicapai dengan hidrolisis agar dapat dipecah terlebih dulu menjadi senyawa yang lebih sederhana agar dapat melewati dinding usus. Karbohidrat dihidrolisis dengan bantuan enzim amylase untuk dapat menjadi bentuk yang sederhana seperti pati. Pati terhidrolisis oleh enzim amylase menjadi unit-unit yang lebih kecil (gula sederhana). Semakin tinggi daya cerna suatu pati berarti semakin banyak pati yang dapat dihidrolisis dalam waktu tertentu yang ditunjukkan oleh semakin banyaknya glukosa dan maltosa yang dihasilkan.

Daya cerna pati dipengaruhi oleh komposisi amilosa dan amilopektin. Sampai saat ini masih terjadi perbedaan pendapat diantara ilmuwan mengenai kecepatan pencernaan pati, hubungannya dengan kandungan amilosa-amilopektin. Sebagian besar ilmuwan berpendapat bahwa amilosa dicerna lebih lambat dibandingkan amilopektin, karena amilosa merupakan polimer dari gula sederhana dengan rantai lurus, tidak bercabang. Rantai yang lurus ini menyusun ikatan amilosa yang solid sehingga tidak mudah tergelatinasi. Oleh karena itu amilosa lebih sulit dicerna dibandingkan dengan amilopektin yang merupakan polimer gula sederhana, bercabang dan struktur terbuka. ${ }^{5}$

Berdasarkan karakteristik tersebut maka pangan yang mengandung amilosa tinggi memiliki aktivitas hipoglikemik lebih tinggi dibandingkan dengan pangan yang mengandung amilopektin tinggi. Namun sebaliknya, berdasarkan mekanisme hidrolisis enzimatik, amilosa dapat dihidrolisis hanya dengan satu enzim yaitu $\alpha$-amilase. Sedangkan amilopektin, karena mempunyai rantai cabang, maka pertama kali yang dihidrolisis adalah bagian luar oleh $\alpha$-amilase, kemudian dilanjutkan oleh $\alpha(1-6)$ glukosidase. Selain itu, berat molekul amilopektin lebih besar dibandingkan dengan amilosa. Berdasarkan pertimbangan ini, maka amilopektin memerlukan waktu yang lebih lama untuk dicerna dibandingkan dengan amilosa. ${ }^{6}$

Kadar amilosa dan amilopektin pada pati sagu memengaruhi sifat dari pati itu sendiri. Apabila kadar amilosa tinggi, maka pati akan bersifat kering, kurang lekat, dan cenderung menyerap air lebih banyak (higrokopis).

Selain sifat pati yang dimiliki oleh sagu, kandungan kalori dalam sagu juga tidak kalah dengan pangan lainnya baik beras, jagung, bahkan kentang, sukun, ubi kayu dan ubi jalar. Kandungan protein sagu memang rendah, namun dapat dilengkapi dengan protein ikan dan sayuran melalui menu makan seperti papeda dan atau sagu lempeng + ikan kuah, ikan bakar + colocolo + sayuran (menu sagu khas Maluku).

Sampel yang diberi makan nasi (kelompok kontrol) mengalami penurunan berat badan dari 194 g menjadi 165 g. Hal ini menunjukkan adanya penurunan berat badan secara bermakna $(\mathrm{p}=0,001)$ yang diuji dengan menggunakan Uji Wilcoxon.

Penurunan berat badan pada kelompok sampel yang diberi makan nasi ini dapat disebabkan oleh karena kandungan karbohidrat yang kurang bila dibandingkan dengan sagu yaitu sebesar 79 g. Selain karbohidrat yang kurang, nasi juga memiliki kandungan kalsium yang tinggi bila dibanding dengan sagu. Kelebihan kadar kalsium dalam nasi akan semakin meningkatkan ekskresi kalsium dalam feses yang dapat memengaruhi proses metabolisme dalam tubuh dan selebihnya akan diekskresikan melalui feses. 
Tingginya kalsium dalam tubuh akan menurunkan sekresi hormon paratiroid, meningkatkan hormon kalsitonin, serta menekan penggunaan protein, lemak, vitamin, mineral $\mathrm{P}, \mathrm{Mg}, \mathrm{F}, \mathrm{I}, \mathrm{Zn}$, dan $\mathrm{Mn}$. Kadar kalsium melebihi $2 \%$ dapat menurunkan penggunaan pakan serta menurunkan pertambahan bobot hidup. ${ }^{7}$

Selain kandungan dalam nasi, dalam penelitian ini ada beberapa faktor yang mungkin dapat menyebabkan penurunan berat badan dari kelompok nasi (kelompok kontrol ini), diantaranya yaitu saat diberi makan ada beberapa hewan coba yang tidak makan habis, sesuai porsi yang diberikan karena dimuntahkan sebagaian nasi yang diberiakan. Selain itu kadar air yang dicampuri dengan nasi juga lebih dari yang ditentukan; hal ini dapat menyebabkan kandungan karbohidrat dalam nasipun menjadi berkurang.

\section{SIMPULAN}

Berdasarkan hasil penelitian maka dapat disimpulkan bahwa pemberian sagu dapat meningkatkan berat badan secara bermakna.

\section{DAFTAR PUSTAKA}

1. Prasetio T, Entin M, Nur RM. Aplikasi untuk diagnosa gizi pada Balita serta kandungan kalori yang diperlukan guna mendapatkan gizi seimbang menggunakan metode Fuzzy Sugeno.
Surabaya: Institut Teknologi Sepuluh November.

2. Tarigan V. Optimalisasi formula tepung sagu terhadap karakteristik beras analog ubi kayu. Universitas Pasundan Bandung. 2013. [cited 2015 Jan 22]. Available from: http://digilib.unpas.ac.id.

3. Alfons JB, Rivaie AA. Sagu mendukung ketahanan pangan dalam menghadapi dampak perubahan iklim. Perspektif. 2011;10(2):81-91.

4. Mien K, Hegar B, Budi AP. Pengaruh penambahan Bifidobacterium dalam susu terhadap perkembangan mikroflora saluran cerna anak usia 12-24 bulan. Sari Pediatri. 2007;9(2):87-92.

5. Bastian F. Hibah Penulisan Buku Ajar Tenaga Akademik Teknologi Pati dan Sagu. Makassar: Fakultas Pertanian Universitas Hasanuddin, 2011.

6. Yuliasih I, Irawadi TT, Sailah I, pranamuda $H$, Setyowati $K$, Sunarti TC. Pengaruh proses fraksinasi pati sagu terhadap karakteristik fraksi amilosanya. J Tek Ind Pert. 2008;17(1):29-36.

7. Warsono IU, Fattah MW, Parakkasi A. Pengaruh tepung cangkang rajungan (Portunus pelagicus) dalam ransum terhadap kadar kolestrol serum dan pertambahan bobot badan tikus putih (Rattus norvegicus). Media Peternakan. 2004; 27(2):55-62. 